\title{
Milk quality and financial management at different scales of production on dairy farms located in the south of Minas Gerais state, Brazil ${ }^{1}$
}

\author{
Marcel Gomes Paixão ${ }^{2 *}$, Marcos Aurélio Lopes ${ }^{3}$, Geraldo Márcio da Costa ${ }^{3}$, Guilherme Nunes de Souza $a^{4,5}$, \\ Luiz Ronaldo de Abreu², Sandra Maria Pinto ${ }^{2}$
}

$10.1590 / 0034-737 X 201764030001$

\begin{abstract}
The objective of this study was to analyze the relationship between aspects related to financial management and scale of production with quality traits (total bacteria count - TBC; somatic cell count - SCC) and composition (protein, fat, lactose, total solids, and non-fat solids) of refrigerated bulk tank milk from 100 dairy farmers located in the south of Minas Gerais state, Brazil, by application of a semi-structured questionnaire. Dairy farmers were categorized according to the daily milk production: small (lower than $150 \mathrm{~L}$ ); medium ( 151 to $500 \mathrm{~L}$ ); and large (higher than $501 \mathrm{~L}$ ). Chi-square tests and identification of possible relative risks between financial aspects and current regulation standards (Normative Instruction No. 62 of December 29, 2011, Ministry of Agriculture, Livestock and Supply) associated to TBC (higher $300,000 \mathrm{CFU} / \mathrm{mL}$ ) and SCC (higher than 500,000 cells $/ \mathrm{mL}$ ) means from bulk tank milk among different milk scales productions were performed. Bulk tanks milk composition met the legislation standards and had not differ between scales of production; however, SCC means within all scales, and TBC of small farmers had not attended the legislation standards and differences were identified $(P \leq 0.05)$. Regarding the financial management aspects, most farmers had no control over incomes, costs, nor calculated milk production cost, with decreased incidences as scale of production increased. Chi-square tests identified that producers that had no concern about milk quality payment bonuses had TBC means 2.95 times more likely $(P \leq 0.05)$ to be above the current regulations. Small dairy farmers had a greater negligence of the costs management and hygienic milk production as compared to medium and large farmers.
\end{abstract}

Key words: somatic cell count; total bacterial count; management; dairy cattle.

\section{RESUMO}

\section{Qualidade do leite e gestão financeira em diferentes escalas de produção em propriedades leiteiras localizadas no sul de Minas Gerais, Brasil}

Objetivou-se analisar a relação de aspectos referentes a gestão financeira e escala de produção com a qualidade (contagem de bactérias totais - CBT; contagem de células somáticas - CCS) e composição (proteína, gordura, lactose, sólidos totais e sólidos desengordurados) do leite cru refrigerado de tanques referentes a 100 propriedades leiteiras do sul de Minas Gerais, atráves da aplicação de questionários semiestruturados. Agrupou-se os produtores conforme as produções diárias de leite: pequenos (menor que 150 L); médios (151 a 500 L) e grandes (maior que $501 \mathrm{~L}$ ). Realizou-se testes "qui-quadrados" e de riscos relativos entre as questões financeiras e as adequações à normativa vigente (Instrução normativa n 62 de 29 de dezembro de 2011, Ministério da Agricultura, Pecuária e Abastecimento) referentes às

\footnotetext{
Submitted on April $22^{\text {th }}, 2014$ and accepted on April 19 $9^{\text {th }}, 2017$

${ }^{1}$ This study is part of the first author's Master's dissertation.

2 Universidade Federal de Lavras, Departamento de Ciência dos Alimentos, Lavras, Minas Gerais, Brazil. marcel.paixao@yahoo.com.br; luizronaldo@dca.ufla.br; sandra@dca.ufla.br

${ }^{3}$ Universidade Federal de Lavras, Departamento de Medicina Veterinária, Lavras, Minas Gerais, Brazil. malopes@dmv.ufla.br; gmcosta@dmv.ufla.br

${ }^{4}$ Embrapa Gado de Leite, Juiz de Fora, Minas Gerais, Brazil. guilherme.souza@embrapa.br

${ }^{5}$ Universidade Federal Fluminense, Departamento de Saúde Coletiva Veterinária e Saúde Pública, Niterói, Rio de Janeiro, Brazil. guilherme.souza@embrapa.br

*Corresponding author: marcel.paixao@yahoo.com.br
} 
médias de CBT (> 300.000 UFC/mL) e CCS (> 500.000 células $/ \mathrm{mL}$ ) e entre as diferentes escalas de produção. A composição do leite, em todas as escalas, atendiam a normativa e não diferiram; porém, as médias de CCS, em todas as escalas, e as de CBT nos pequenos produtores, não atendiam, sendo verificadas diferenças $(P \leq 0,05)$. Quanto ao gerenciamento, a maioria não controlava as receitas e despesas e não estimavam o custo de produção, com incidências decrescentes tanto quanto maior a escala. Os testes "qui-quadrados" revelaram que os produtores que não possuíam conhecimento do preço pago pelas bonificações pela qualidade do leite apresentaram 2,95 vezes mais chances $(P \leq 0,05)$ da CBT estar acima do estabelecido pela normativa vigente. Verificou-se que os pequenos produtores apresentaram maior descaso no controle gerencial e na produção higiênica do leite, quando comparados aos médios e grandes.

Palavras-chave: contagem de células somáticas; contagem bacteriana total; gerenciamento; bovinocultura leiteira.

\section{INTRODUCTION}

Dairy activity is present all over Brazil, and it generates income, taxes and jobs. Minas Gerais state deserves special attention in this activity, and in the third quarter of 2013 it produced 1,553,256 million of liters of milk, representing $25.9 \%$ of this country total supply within this period, a slightly higher production as compared to the same period of 2012 within this state (IBGE, 2013). However, the Brazilian milk production chain has undergone a series of transformations, or a restructuring process, which had generated a series of consequences for the different agents involved. It can be observed that the primary production has become more dependent on industry, losing autonomy over its production processes and scale of production (Bortoleto, 2000).

The globalization of the economy and its follow competitiveness, have turned milk quality traits (somatic cell count and total bacterial count) in the main concern for the production chain in order to obtain good economic results (Vieira, 2010). In this scenario, dairy industries started to establish new conditions for the acquisition of bulk tank milk, by remunerating farmers that produced milk with quality and in larger volumes, in order to obtain dairy products with higher industrial yield and better sensorial aspects, reduction of transport costs, and optimization of milk supply routes.

Several reasons contribute to explain these previous cited changes, e.g., the lack of milk quality standardization and volumes of raw milk offered to industry (Martins, 1999). These transformations in the milk production chain and market have concerned the dairy farmers on the need of a good management of the activity, which leaded to a more efficient and competitive production; and thus farmers have been assuming a businessman position and leaving behind the amateurism, by establishing permanent financial management regardless of their production system size (Lopes et al., 2010).
Recent studies have studied some milk quality traits (milk composition and hygienic-sanitary aspects - SCC and $\mathrm{TBC}$ ) and its association with different production scales (Borges et al., 2013; Bodenmüller et al., 2010), while others have studied technical and management efficiency of dairy farmers and its association with different scales of production (Fassio et al., 2005; Gonçalves et al., 2008; Lopes et al., 2008). However, there are no studies associating both milk quality traits and financial management of dairy farms within different scales of production. It is well known that to raise productivity and bulk milk quality (e.g., adequate levels of total solids and hygienic-sanitary traits) in a herd, the income of dairy activity is, at least in part, the main key to achieved this goal; because it allows investments that can raise productivity with a rapidly payback period, and also contributes to the whole milk production process as investments in herd sanity, feed, and establishment of good agricultural practices for milk quality (Paixão et al., 2014).

The objective of this study was to analyze the relationship between some aspects related to financial management and scale of production with milk quality outcomes of 100 dairy farms located in six counties in the south of Minas Gerais state, Brazil.

\section{MATERIAL AND METHODS}

Prior to the study, of the total of 13 milk supply lines and 150 dairy farmers suppliers from a dairy industry located in Lavras county, Minas Gerais state, Brazil, 10 milk supply lines and 100 dairy farms were randomly select to participated. The selected farms, located in the counties of Lavras (12), Ijaci (34), Ribeirão Vermelho (3), Itumirim (31), Bom Sucesso (10) and Ibituruna (10) were mapped during November to December 2011 using a Garmin ${ }^{\circledR}$ Etrex Vista HCX Global Positioning System (GPS), followed by transference of the data to a computer using GPS Trackmaker ${ }^{\circledR}$ software version 13. 
A semi-structured questionnaire with questions related to general aspects of production and financial management of the farms was elaborated and applied from January to April 2012 in the selected farms. The data was transferred to an electronic spreadsheet and answers were grouped by categorization and frequency. Categorical (qualitative) data were transcribed according to its category code, while open questions and quantitative data were categorized before transcription. Farmers were grouped according to daily milk scales of production as previously described by Lopes et al. (2008): small (lower than 151 liters per day); medium (151 to 500 liters per day); and large (higher than 500 liters per day).

Data from bulk milk tank analyses [somatic cell count (SCC), total bacterial count (TBC), fat content, protein, and lactose] and daily production were acquired from the dairy industry milk quality extension team, and means were calculated from an interval period of 12 months of analyses (at least one bulk tank milk analyses per month - six months prior and after the beginning of the study, respectively). In cases where farmers no longer sold the milk to the dairy industry during this interval period, data from the previous 12 months prior to their exit were used for calculus. In order to obtain a normal distribution of the data for TBC and SCC means calculus, a logarithmic transformation $\left(\log _{10}\right)$ were performed before analyses of variance (ANOVA).

The bulk milk tank samples were collected by the dairy industry milk quality extension team, properly packaged and sent to Clínica do Leite, at "Luiz de Queiroz" School of Agriculture (ESALQ/USP) monthly. Milk composition and SCC analyses were performed on Bentley Combi System $2300^{\circledR}$ electronic equipment and TBC analyses were performed on IBC BactoCount ${ }^{\circledR}$ electronic equipment (Bentley Instruments Incorporated, Chaska, United States of America).

Analyses of variance and means tests were performed using SISVAR (Statistical Analysis System) software by the Scott-Knott test (Ferreira, 2008). Chi-square tests and relative risks between variables were performed using SPSS Statistics ${ }^{\circledR} 17.0$ software (SPSS, 2008). Each outcome were classified in two categories (problematic and control) and scales of production in three categories (small, medium, large) prior to the chi-square tests. Factors associated at $P$ $\leq 0.05$ were considered significant if the inferior confidence interval (ICI) and the superior confidence interval (ICS) had values higher than 1 .

\section{RESULTS AND DISCUSSION}

The descriptive characteristics of the 100 enrolled dairy farms located in six different counties in the southern region of the state of Minas Gerais classified by scales of

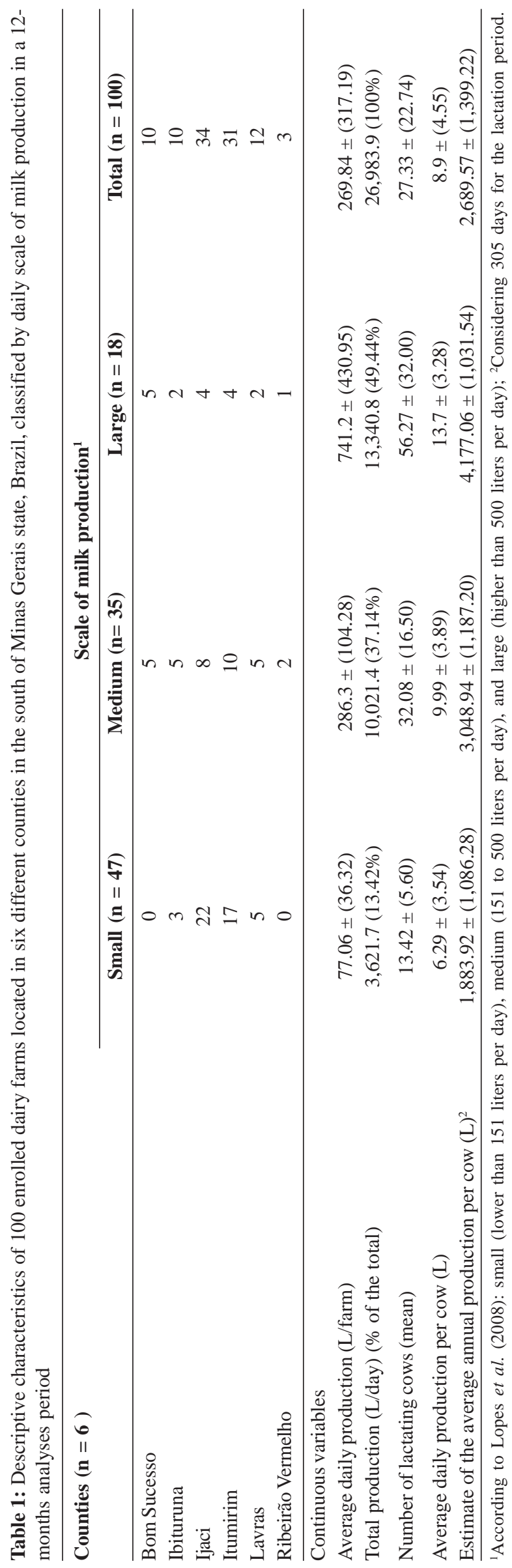

Rev. Ceres, Viçosa, v. 64, n.3, p. 213-221, mai/jun, 2017 
production are described in Table 1. It can be observed that the majority of farmers produced less than 151 liters daily, accounting for only $13.42 \%$ of the company's total daily milk supply.

The average daily production was 269.84 liters per farm (Table 1), higher than previously reported in Brazil (52 L/ farm/day) and in Minas Gerais state (88 L/farm/day) in the year of 2006 (Zoccal, 2008). According to this author, although an increase was observed in the last decade in the daily milk supply from Brazilian farmers, the production per farm still lower as compared to international standards, because countries such United States, New Zealand and Australia production vary from 2,000 to 3,000 L/farm/day.

The average number of lactation cows per farm was 27.33. The overall average for daily milk production per cow during the study period was $8.9 \mathrm{~L}$ (Table 1 ), higher than the Brazilian average $(5.1 \mathrm{~L} /$ cow/day) in the year of 2011 (SEAB, 2013). The estimated milk production per cow/ year, considering a lactation period of 305 days, was 2,689.57 ( $\pm 1,399.22)$ L; lower than previously described by Fassio et al. (2006) (4,157 L/cow/year) in the state of Minas Gerais, but higher than this country average (1,394 L/ cow/year) (Embrapa, 2010) and similar with values from higher producing regions $(2,628 \mathrm{~L} / \mathrm{cow} /$ year $)$ such as north of Rio Grande do Sul, west of Santa Catarina, and southwest of Paraná, Brazil (Zoccal et al., 2011).

Means of bulk tank milk composition analyses from the 100 enrolled dairy farms located in six different counties in the south of Minas Gerais state, Brazil, classified by daily scale of production in a 12-months analyses period are presented in Table 2. We identified that all composition traits were in compliance with the current normative of milk quality in Brazil (Normative Instruction No. 62, of 2011) which standardize the minimum values for protein, fat and non-solids fat of $2.9 \mathrm{~g} / 100 \mathrm{~g} ; 3.0 \mathrm{~g} / 100 \mathrm{~g}$; and $8.4 \mathrm{~g} / 100 \mathrm{~g}$ for refrigerated raw milk (Brazil, 2011) respectively. Milk composition traits had not differed within daily production scales $(P \leq 0.05)$.

Protein means in our study were higher as compared to Borges et al. (2013) (ranging from 3.0 to $3.15 \mathrm{~g} / 100 \mathrm{~g}$ ) that studied milk composition at different production scales in 183 dairy farms located in Central Mineira and Minas West mesoregions in the state of Minas Gerais. These authors also had not identified statistical differences in protein means within different scales of production. According to Stelwagen (2011) protein levels in bulk tank milk is associated to genetic and non-genetic factors (diet, endocrine factors, environmental temperature, milking frequency, lactation stage and mastitis).

Fat mean values in our study (3.68 g/100g - Table 2) were similar to results previously reported by Bodenmüller et al. (2010) (3.72 g/100g) of 1,196 dairy farms bulk milk tank analyses from a dairy industry located in Londrina, Paraná, Brazil. Fat content had the higher variation among milk components, and according to McGuire et al. (2011) this variation is associated to breed, diet, lactation stage, season, environment temperature, and body score condition of the animals.

Our lactose means ranged from 4.49 to $4.52 \mathrm{~g} / 100 \mathrm{~g}$ (Table 2) and it was slightly higher than those previously reported by Borges et al. (2013) (4.37 to $4.47 \mathrm{~g} / 100 \mathrm{~g}$ ). According to Bodenmüller et al. (2010) somatic cell count and total bacterial count has a positive association with milk lactose, thus, this milk component is impaired when milk sanitary-hygiene aspects are poorly handled.

Our total and non-fat solids results were similar than previously reported by Ribas et al. (2004) (12.32 and 8.62\% for total and non-fat solids respectively) in a study that enrolled 257,540 bulk milk samples from 3 Brazilian states (Paraná, Santa Catarina and São Paulo) during January 1999 and November 2001. Paiva et al. (2012) stated that an increase in the raw milk solids content is crucial for the dairy industry in order to raise its products yield, and thus, increasing the competitiveness both in national and international dairy products market.

Means and standard deviations of the total bacterial count (TBC) and somatic cell count (SCC) analyses of bulk tank milk from 100 enrolled dairy farms located in six different counties in the south of Minas Gerais state, Brazil, classified by daily scale of production in a 12-months analyses period

Table 2: Means followed by the standard deviations of bulk tank milk composition analyses from 100 enrolled dairy farms located in six different counties in the south of Minas Gerais state, Brazil, classified by daily scale of production in a 12-months analyses period

\begin{tabular}{|c|c|c|c|c|c|}
\hline \multirow{2}{*}{ Variable } & \multicolumn{3}{|c|}{ Scale of milk production ${ }^{1}$} & \multirow[b]{2}{*}{$\mathrm{CV}(\%)^{2}$} & \multirow[b]{2}{*}{ All $(n=100)$} \\
\hline & Small $(n=47)$ & Medium $(\mathrm{n}=35)$ & Large $(n=18)$ & & \\
\hline Protein (g/100g) & $3.21^{\mathrm{a}} \pm(0.12)$ & $3.21^{\mathrm{a}} \pm(0.12)$ & $3.21^{\mathrm{a}} \pm(0.06)$ & 3.50 & $3.21 \pm(0.11)$ \\
\hline Fat $(g / 100 g)$ & $3.71^{\mathrm{a}} \pm(0.36)$ & $3.65^{\mathrm{a}} \pm(0.24)$ & $3.64^{\mathrm{a}} \pm(0.22)$ & 8.16 & $3.68 \pm(0.30)$ \\
\hline Lactose $(\mathrm{g} / 100 \mathrm{~g})$ & $4.53^{\mathrm{a}} \pm(0.10)$ & $4.49^{\mathrm{a}} \pm(0.10)$ & $4.50^{\mathrm{a}} \pm(0.07)$ & 2.12 & $4.51 \pm(0.10)$ \\
\hline Total solids (g/100g) & $12.38^{\mathrm{a}} \pm(0.43)$ & $12.29^{\mathrm{a}} \pm(0.36)$ & $12.28^{\mathrm{a}} \pm(0.25)$ & 3.07 & $12.33 \pm(0.38)$ \\
\hline Non-fat solids (g/100g) & $8.66^{\mathrm{a}} \pm(0.17)$ & $8.65^{\mathrm{a}} \pm(0.17)$ & $8.63^{\mathrm{a}} \pm(0.19)$ & 1.87 & $8.65 \pm(0.16)$ \\
\hline
\end{tabular}

Means within a line with different superscripts differs in ANOVA test $(P \leq 0.05) ;{ }^{2} \mathrm{CV}=\mathrm{Coefficient}$ of variation. ${ }^{1}$ According to Lopes et al. (2008): small (lower than 151 liters per day), medium (151 to 500 liters per day), and large (higher than 500 liters per day). 
are presented in Table 3. Our TBC results of small farmers was higher than the minimum standards $(300,000 \mathrm{CFU} / \mathrm{mL})$ from the current legislation (Normative Instruction number 62 of December 29, 2011, in the South, Southeast and WestCenter regions, with dates from September 1, 2013) (Brasil, 2011); but in accordance with the same legislation at the time of the analysis in such region $(600,000 \mathrm{CFU} / \mathrm{mL})$. Our $\log _{10}$ TBC means of small farmers were greater as compared to medium and large farmers $(P \leq 0.05)$ (Table 3$)$. This results suggest that small farmers probably has smaller incomes, in concordance with Alves et al. (2004) which affirms that small farmers faces many financial difficulties in order to optimize production and many times they remain outside the process of modernization of agriculture, and thus directly impairing the quality of milk produced.

Small farmers also had a low contribution in the total volume of milk supplied to the dairy industry in study (13.42\%), but its contribution to the total milk TBC rate (calculated by multiplying the volume of milk collected on each farm by the number of its CFU/mL, and divided by the sum of the total milk volume multiplied by its $\mathrm{CFU} / \mathrm{mL}$ ) was high $(34.71 \%)$ (Table 3$)$. This results show the importance of strategic plans in order to improve hygienic aspects during milking routine and refrigeration of milk. A proper milking routine should include the correct sanitization of utensils, milking equipment, milking clean cows, and a periodical check for the bulk tank temperature (Paixão et al., 2014), because a small volume of milk with a very high load of microorganisms can influence the quality of the milk truck.

The SCC mean within all farmers scales were not in compliance with the current legislation $(500,000$ cells $/ \mathrm{mL})$ but were in compliance at the period of collection (2011) $(600,000$ cells $/ \mathrm{mL}$ ) (Normative Instruction No. 62) (Table $3)$. The contribution rate of SCC of each daily production scale in the total SCC was similar to the percentages of contributions in the volume of milk collected daily. Besides lactose means within all daily production scales farmers did not statistically differ $(P \leq 0.05)$, medium farmers that had a greater SCC means also presented a slightly lower lactose means as compared to small and large farmers, in agreement with Borges et al. (2013) who identified a similar situation. According to Shuster et al. (1991) the lower synthesis of lactose is caused by destruction of the secretory tissue, leading to a leakage of lactose from the alveolus to the bloodstream due to an increased permeability of the membrane, and also by lactose fermenters intramammary pathogens.

The frequency of farms and relative risks of financial management aspects associated to bulk tank milk total bacterial count (TBC) and somatic cell count (SCC) higher than the standard values of the legislation from the 100 enrolled dairy farms located in six different counties in the south of Minas Gerais state, Brazil, classified by daily

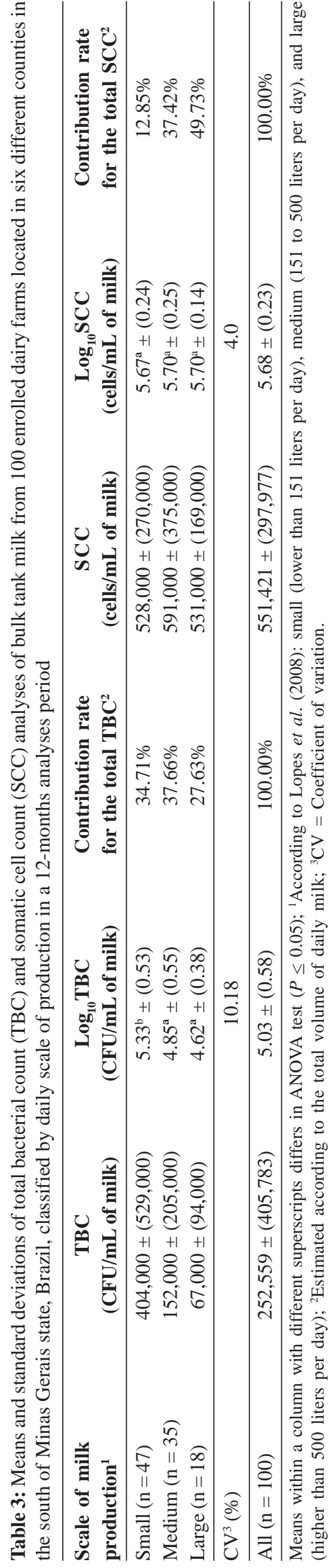

Rev. Ceres, Viçosa, v. 64, n.3, p. 213-221, mai/jun, 2017 
70 Table 4: Frequency of farms and relative risks of financial management aspects associated to bulk tank milk total bacterial count (TBC) and somatic cell count (SCC) higher than reference values from current legislation (Normative Instruction number 62, 2011) of 100 enrolled dairy farms located in six different counties in the south of Minas Gerais state, Brazil, classified by daily scale of production in a 12-months analyses period

\begin{tabular}{|c|c|c|c|c|c|c|c|c|c|c|c|}
\hline \multirow{4}{*}{ Question } & \multirow{4}{*}{ Cat. $^{2}$} & \multicolumn{5}{|c|}{ Scale of milk production ${ }^{1}$} & \multirow{3}{*}{\multicolumn{2}{|c|}{$\begin{array}{l}\text { Large } \\
\mathrm{n}=18\end{array}$}} & \multirow{4}{*}{ Ref. $^{3}$} & \multirow{4}{*}{$P$-value } & \multirow{4}{*}{$\mathbf{O R}^{4}$} \\
\hline & & \multirow{3}{*}{$\begin{array}{c}\text { All } \\
\mathbf{n}=\mathbf{1 0 0}\end{array}$} & \multirow{2}{*}{\multicolumn{2}{|c|}{$\begin{array}{c}\text { Small } \\
n=47\end{array}$}} & \multirow{2}{*}{\multicolumn{2}{|c|}{$\begin{array}{r}\text { Medium } \\
\mathbf{n}=35\end{array}$}} & & & & & \\
\hline & & & & & & & & & & & \\
\hline & & & $\mathbf{n}$ & $\%$ & $\mathbf{n}$ & $\%$ & $\mathbf{n}$ & $\%$ & & & \\
\hline $\mathrm{TBC} \times 10^{3}(\mathrm{CFU} / \mathrm{mL}$ of milk) & $\leq 300$ & 76 & 28 & 59.6 & 31 & 88.6 & 17 & 94.4 & $\mathrm{SCC}^{6}$ & 0.822 & 1.11 \\
\hline IDC X IV(CFU/IIL OI IIIIK) & $>300^{\dagger}$ & 24 & 19 & 40.4 & 4 & 11.4 & 1 & 5.6 & & & \\
\hline $\mathrm{SCC} \times 10^{3}(\mathrm{cells} / \mathrm{mL}$ of milk $)$ & $\leq 500$ & 52 & 25 & 53.2 & 18 & 51.4 & 9 & 50.0 & $\mathrm{TBC}^{5}$ & 0.822 & 1.11 \\
\hline SC $\times 10$ (CEIIS/IIL OI IIIIK) & $>500^{\dagger}$ & 48 & 22 & 46.8 & 17 & 48.6 & 9 & 50.0 & & & \\
\hline Do you control the incomes? & Yes & 23 & 4 & 8.5 & 12 & 35.3 & 7 & 46.7 & $\mathrm{TBC}^{5}$ & 0.334 & 1.79 \\
\hline 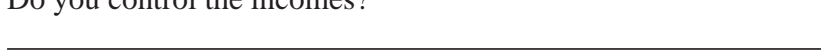 & $\mathrm{No}^{\dagger}$ & 73 & 43 & 91.5 & 22 & 64.7 & 8 & 53.3 & $\mathrm{SCC}^{6}$ & 0.343 & 0.63 \\
\hline Do you control the costs? & Yes & 25 & 4 & 8.5 & 14 & 41.2 & 7 & 46.7 & $\mathrm{TBC}^{5}$ & 0.502 & 1.46 \\
\hline & $\mathrm{No}^{\dagger}$ & 71 & 43 & 91.5 & 20 & 58.8 & 8 & 53.3 & $\mathrm{SCC}^{6}$ & 0.160 & 0.51 \\
\hline Do you use spreadsheet for costs? & Yes & 16 & 2 & 4.4 & 8 & 24.2 & 6 & 40.0 & TBC $^{5}$ & 0.612 & 1.42 \\
\hline & $\mathrm{No}^{\dagger}$ & 77 & 43 & 95.6 & 25 & 75.8 & 9 & 60.0 & $\mathrm{SCC}^{6}$ & 0.181 & 0.47 \\
\hline Do you know how much is your production cost? & Yes & 17 & 5 & 10.9 & 7 & 21.2 & 5 & 33.3 & $\mathrm{TBC}^{5}$ & 0.178 & 2.80 \\
\hline & $\mathrm{No}^{\dagger}$ & 77 & 41 & 89.1 & 26 & 78.8 & 10 & 66.7 & $\mathrm{SCC}^{6}$ & 0.644 & 0.78 \\
\hline Do you know how much you are paid for milk quality & Yes & 38 & 12 & 26.7 & 17 & 51.5 & 9 & 60.0 & $\mathrm{TBC}^{5}$ & 0.048 & 2.95 \\
\hline & $\mathrm{No}^{\dagger}$ & 55 & 33 & 73.3 & 16 & 48.5 & 6 & 40.0 & $\mathrm{SCC}^{6}$ & 0.496 & 0.75 \\
\hline
\end{tabular}

${ }^{1}$ According to Lopes et al. (2008): small (lower than 151 liters per day), medium (151 to 500 liters per day), and large (higher than 500 liters per day); ${ }^{2}$ Cat. $=$ Categories [OR estimated for the problematic category $\left(^{\dagger}\right)$ as compared to the non-problematic for TBC or SCC response variable]. When the number of frequencies differs from the total of cases, data were lost. ${ }^{3}$ Ref $=$ Referential response variable of the chi-square test and relative risks (TBC or SCC); ${ }^{4} \mathrm{OR}=$ Relative risks (odds ratio); ${ }^{5} P$-value estimated for TBC higher than referential values $\left(300,000 \mathrm{CFU} / \mathrm{mL}\right.$ of milk); ${ }^{6} P$-value estimated for SCC higher than referential values $(500,000$ cells $/ \mathrm{mL}$ of milk). 
scale of production in a 12-months analyses period are presented in Table 4 . We identified that $40.4 \%$ of the total of small farmers had TBC means higher than the legislation limits. Similar proportions within daily milk production scales farmers had SCC above the legislation limits (varying from $46.8 \%$ to $50.0 \%$ for small and large farmers, respectively) (Table 4). In agreement with our study, Mattioda \& Bittencourt (2010) studying different production scales milk farmers in the region of Fernandes Pinheiro, Pará state, Brazil, also identified that smaller farmers had greater bulk tank milk TBC as compared to the others categories of farmers.

We identified that the majority of farmers had no control over incomes (including raw milk vending, animals and manure), but small farmers had the highest absence of incomes control (Table 4), which suggest the lack of professionalism within these farmers classes. According to Oliveira \& Pereira (2009), the sustainability of a particular activity, or, in other words, its long-term survival capacity, is directly associated with its economic management.

Most farmers had no control over their costs, and the greater proportion of them was classified under the small farmer category. Spreadsheets were not used for costs control in one-third of the farmers which declared that had it under control. The use of spreadsheets, both electronic or a simple field notebook, are essential for financial costs control, because it facilitate the division of expenses into groups and assist milk quality extension teams and farmers to make future decisions (Lopes \& Lopes, 1999). The majority of farmers $(77 \%)$ reported that they were unaware of their average cost of production; and one farmer reported that knew their costs of production, but do not use a spreadsheet to record it. According to Gomes \& Alves (1999), the correct determination of the dairy farm activity production cost is complex, due to its complexity, such as incomes that proceed from meat vending along with milk, family labor, and continuous production.

The majority $(55 \%)$ of the farmers reported that do not know how much the dairy industry pay for milk quality bonuses neither how much this extra income can represents monthly; and a higher proportion was identified among small farmers as compared to medium and large farmers. Paixão et al. (2014) studying different hypothetical scenarios in order to calculate the implementation costs of different levels of good agricultural practices (GAP) (low,

Table 5: Chi-square tests and relative risks of different scales of productions associated to financial management aspects and hygiene-sanitary quality of bulk tank milk in a 12-months analyses period from 100 enrolled dairy farms located in six different counties in the south of Minas Gerais state, Brazil

\begin{tabular}{|c|c|c|c|c|c|}
\hline \multirow{2}{*}{ Question $^{1}$} & \multirow{2}{*}{$\begin{array}{c}\text { Scale of } \\
\text { milk production }{ }^{2}\end{array}$} & \multirow{2}{*}{$P$-value } & \multirow{2}{*}{$\mathbf{O R}^{3}$} & \multicolumn{2}{|c|}{$\mathrm{CI}^{4}(95 \%)$} \\
\hline & & & & ICI $^{5}$ & SCI $^{6}$ \\
\hline \multirow{3}{*}{$\begin{array}{l}\text { Do you control the incomes? } \\
\text { (no }{ }^{\dagger} \text { vs. yes) }\end{array}$} & Small vs. Medium & 0.005 & 5.9 & 1.7 & 20.3 \\
\hline & Small vs. Large & 0.002 & 9.4 & 2.2 & 39.8 \\
\hline & Medium vs. Large & 0.451 & 1.6 & 0.5 & 5.5 \\
\hline \multirow{3}{*}{$\begin{array}{l}\text { Do you control the operational costs? } \\
\text { (no } \text { no }^{\dagger} \text {. yes) }\end{array}$} & Small vs. Medium & 0.001 & 7.5 & 2.2 & 25.8 \\
\hline & Small vs. Large & 0.002 & 9.4 & 2.2 & 39.7 \\
\hline & Medium vs. Large & 0.720 & 1.2 & 0.4 & 4.2 \\
\hline \multirow{3}{*}{$\begin{array}{l}\text { Do you use spreadsheet for the costs? } \\
\text { (no }{ }^{\dagger} \text { vs. yes) }\end{array}$} & Small vs. Medium & 0.020 & 6.9 & 1.3 & 34.9 \\
\hline & Small vs. Large & 0.003 & 14.3 & 2.5 & 82.8 \\
\hline & Medium vs. Large & 0.266 & 2.0 & 0.5 & 7.6 \\
\hline \multirow{3}{*}{$\begin{array}{l}\text { Do you know how much is your production cost? } \\
\text { (no }{ }^{\dagger} v s . \text { yes) }\end{array}$} & Small vs. Medium & 0.214 & 2.2 & 0.6 & 7.6 \\
\hline & Small vs. Large & 0.050 & 4.1 & 1.0 & 16.9 \\
\hline & Medium vs. Large & 0.369 & 1.8 & 0.4 & 7.2 \\
\hline \multirow{3}{*}{$\begin{array}{l}\text { Do you know how much you are paid for milk quality bonuses? } \\
\text { (no }{ }^{\dagger} v s . \text { yes) }\end{array}$} & Small vs. Medium & 0.027 & 2.9 & 1.1 & 7.5 \\
\hline & Small vs. Large & 0.024 & 4.1 & 1.2 & 14.0 \\
\hline & Medium vs. Large & 0.584 & 1.4 & 0.4 & 4.9 \\
\hline \multirow{3}{*}{$\begin{array}{l}\mathrm{TBC}\left(>300^{\dagger} v s . \leq 300\right) \\
(\mathrm{CFU} / \mathrm{mL} \text { of milk }) \times 10^{3}\end{array}$} & Small vs. Medium & 0.006 & 5.2 & 1.6 & 17.3 \\
\hline & Small vs. Large & 0.022 & 11.5 & 1.4 & 94.1 \\
\hline & Medium vs. Large & 0.922 & 0.9 & 0.3 & 2.9 \\
\hline \multirow{3}{*}{$\begin{array}{l}\mathrm{SCC}(>500 \text { vs. } \leq 500) \\
\left(\text { cells } / \mathrm{mL} \text { of milk) } \times 10^{3}\right.\end{array}$} & Small vs. Medium & 0.874 & 0.9 & 0.4 & 2.2 \\
\hline & Small vs. Large & 0.818 & 0.9 & 0.3 & 2.6 \\
\hline & Medium vs. Large & 0.488 & 2.2 & 0.2 & 21.2 \\
\hline
\end{tabular}

${ }^{1}$ Odds ratio and $P$-values calculated for the problematic category $\left({ }^{\dagger}\right)$ as compared to the non-problematic; ${ }^{2}$ According to Lopes $e t$ al . (2008): small (lower than 151 liters per day), medium (151 to 500 liters per day), and large (higher than 500 liters per day); ${ }^{3} \mathrm{OR}=\mathrm{Odds}$ ratio (relative risk); ${ }^{4} \mathrm{CI}=$ Total confidence interval; ${ }^{5} \mathrm{ICI}=$ Inferior confidence interval; ${ }^{6} \mathrm{SCI}=$ Superior confidence interval. 
medium and high) associated to milk quality improvement in a dairy farm, identified that, despite its higher initial investment, producers under the high GAP scenario had a higher and faster economic returns due to higher SCC and TBC bonuses paid from the dairy industry, as compared to the others hypothetical scenarios.

Financial management factors had no association with SCC levels above the current regulations in the chi-square tests. However, farmers that had no information about how much the dairy industry pay for milk quality bonuses had 2.95 times more likely $(P=0.048)$ of TBC means to be above the current regulation as compared to farmers who had information about theses bonuses (Table 4). Our results suggest that simple information about monetary values paid for milk quality bonuses has an impact on farmer's attitude, and thus, an indirect positive impact on the milking routine hygiene.

Chi-square tests and relative risks of different scales of productions associated to financial management aspects and hygiene-sanitary quality of bulk tank milk in a 12months analyses period from 100 enrolled dairy farms located in six different counties in the south of Minas Gerais state, Brazil are presented in Table 5. Small farmers had a greater negligence of costs control and hygienic production of bulk tank milk (TBC), as compared to medium and larger farmers, because from all chi-square tests performed for "small vs. medium" and "small vs. large" farmers, small farmers had an positive association with all negative category $(P \leq 0.05)$, with an exception for the negative categories of the questions "Do you know how much is your production cost?" (no vs. yes) $(P=0.214)$ and for SCC $(>500,000$ cells $/ \mathrm{mL} v s . \leq 500,000$ cells $/ \mathrm{mL})$ (small vs. medium and small vs. large, $P=0.874$ and 0.818 , respectively) (Table 5). Greater odds ratios (relative risks) were identified for "small $v s$. large" as compared to "small $v s$. medium" farmers for all problematic categories tested (with an exception for SCC); in addition, small farmers had 4.1 times more likely to had no information about their production costs $(P=0.05)$ as compared to larger farmers, evidencing that farmers with higher scales of production had greater concerns about management control of their dairy activity as compared to small farmers. An increase on farms productivity without a rapidly investment in technologies or changes in production system - for a better yield of the land, labor and costs - is only possible if the management of the dairy activity is sturdily improved (Ferreira Junior \& Cunha, 2004).

No significant association $(P \leq 0.05)$ was identified between medium and large farmers within all problematic categories tested. Our results indicate that, unlike the small farmers, medium and large scales of production farmers had greater concerns about hygienic quality of milk (TBC) and costs management of their farm.

\section{CONCLUSIONS}

Aspects related to financial management, bulk tanks milk composition and quality traits of 100 dairy farms located in six different counties in the south of Minas Gerais state, Brazil, were studied. Bulk tanks milk composition were in agreement with the current legislation; although, hygienic aspects of milking routine and udder health status from studied herds still requires attention from farmers and milk quality extension teams in order to reduce bulk tank milk TBC and SCC to legislation standards.

Negligence about financial management aspects related to the dairy activity increased as farmer's daily scale of production decreased. Our results suggest that small farmers, which produces milk volumes lower than 150 liters per day, requires special attention from milk quality extension teams in order to improve productivity. Farmers that were aware of milk quality bonuses payment produced milk with a greater hygienic standard, and our results suggest that this awareness has a direct impact on farmer's attitude, and an indirect impact on milking routine hygiene. Field professionals should draw farmer's attention to the benefits that this bonuses has on their monthly income and also consumer's health.

\section{COMMITTEE OF ETHICS ON RESEARCH}

This study was approved and performed in accordance with the technical standards of biosafety and ethics from Plataforma Brasil and registered under protocol number 132.569.

\section{ACKNOWLEDGEMENTS}

To CNPq and FAPEMIG for the financial support and to UFLALEITE study group from Federal University of Lavras for the data collection support.

\section{REFERENCES}

Alves E (2004) Retornos à escala e mercado competitivo: teoria e evidências empíricas. Revista de Economia e Agronegócio, 2:311-334.

Bodenmüller AF, Damasceno JC, Previdelli ITS, Santana RG, Ramos CECO \& Santos GT (2010) Tipologia de sistemas de produção baseada nas características do leite. Revista Brasileira de Zootecnia, 39:1832-1839.

Borges LR, Fonseca LM, Martins RT \& Oliveira MCPP (2013) Milk quality according to the daily range in farm production in the Mesoregion Central Mineira and Oeste of Minas Gerais regions, Brazil. Arquivo Brasileiro de Medicina Veterinária e Zootecnia, 65:1239-1246.

Bortoleto E (2000) Trajetória e demandas tecnológicas nas cadeias agroalimentares do MERCOSUL ampliado. Available at: <http://www 10.iadb.org/intal/intalcdi/PE/2010/05148.pdf>. Accessed on: January $07^{\text {th }}, 2014$. 
Brasil (2011) Instrução normativa $\mathrm{n}^{\circ} 62$, de 29 de dezembro de 2011 - Regulamento Técnico de Produção, Identidade e Qualidade do Leite tipo A, Leite Cru Refrigerado, Leite Pasteurizado, Leite Cru Refrigerado e seu Transporte a Granel. DOU, 30/12/ 2011, Seção 1, p. 6.

Embrapa - Empresa Brasileira de Pesquisa Agropecuária (2010) Produção de leite, vacas ordenhadas e produtividade animal no Brasil - 1980/2010. Available at: <http://www.cnpgl.embrapa.br/ nova/informacoes/estatisticas/producao/tabela0230.php> Accessed on: January 10 $10^{\text {th }}, 2014$.

Fassio LH, Reis RP \& Dos Reis AJ (2005) Custos e shut-down point da atividade leiteira em Minas Gerais. Revista de Economia e Sociologia Rural, 43:759-777.

Fassio LH, Reis RP \& Geraldo LG (2006) Desempenho técnico e econômico da atividade leiteira em Minas Gerais. Revista Ciência e Agrotecnologia, 30:1154-1161.

Ferreira Junior S \& Cunha NRS (2004) Eficiência técnica na atividade leiteira de Minas Gerais: um estudo a partir de três sistemas de produção. In: $42^{\circ}$ Congresso Brasileiro de Economia e Sociologia Rural, Cuiabá. Anais, Sober. CD-ROM.

Ferreira DF (2008) SISVAR: um programa para análises e ensino de estatística. Revista Symposium, 6:36-41.

Gomes AP \& Alves E (1999) Identificando ineficiências na produção de leite. Boletim do Leite, 6:1-2.

Gonçalves RML, Vieira WC, Lima JE \& Gomes ST (2008) Analysis of technical efficiency of milk-producing farms in Minas Gerais. Economia aplicada, 12:321-335.

IBGE - Instituto Brasileiro de Geografia e Estatística (2013) Indicadores IBGE: Estatística da Produção Pecuária Setembro de 2013. Available at: <http://www.ibge.gov.br/home/estatistica/ indicadores/agropecuaria/producaoagropecuaria/abate-leite-couro-ovos_201302_publ_completa.pdf $>$. Accessed on: January $02^{\text {nd }}, 2014$.

Lopes MA, Dias AS, Carvalho FM, Lima ALR, Cardoso MG \& Carmo EA (2010) Efeito do tipo de mão-de-obra nos resultados econômicos de sistemas de produção de leite na região de Lavras (MG) nos anos 2004 e 2005. Revista Brasileira de Agrociência, 16:125-132.

Lopes MA, Dias AS, Carvalho FM, Lima ALR, Cardoso MG \& Carmo EA (2008) Efeito da escala de produção nos resultados econômicos de sistemas de produção de leite na região de Lavras (MG, Brasil), em 2004 e 2005. Asociación Latinoamericana de Producción Animal, 16:129-137.

Lopes MA \& Lopes DCF (1999) Desenvolvimento de um sistema computacional para cálculo do custo de produção do leite. Revista Brasileira de Agroinformática, 2:01-12.

Martins PC (1999) O pró-leite em Juiz de Fora: um caso de sucesso em gestão de propriedades agrícolas. In: Simpósio sustentabilidade da pecuária de leite no Brasil, Goiânia. Anais, Embrapa. p.189-199.
Mattioda F \& Bittencourt JVM (2010) Qualidade do leite de pequenas propriedades rurais da região sudeste do Paraná. In: XXX Encontro nacional de engenharia de produção. Available at: <http://pg.utfpr.edu.br/dirppg/ppgep/ebook/2010/CONGRESSOS/ENEGEP/21.pdf> Accessed on: January 21 st 2014.

Mcguire MA, Baumanm DE \& Harvatine KJ (2011) Mammary Gland, milk biosynthesis and secretion, milk fat. In: Roginski H, Fuquay JW \& Fox PF (Eds.) Encyclopedia of Dairy Sciences. London, Elsevier. p.359-366.

Oliveira AS \& Pereira DH (2009) Gestão econômica de sistemas de produção de bovinos leiteiros. In: $1^{\circ}$ Simpósio brasileiro de agropecuária sustentável, Viçosa. Anais, UFV. p.106-133.

Paiva CAV, Cerqueira MMOP, Souza MRS \& Lana AMQ (2012) Evolução anual da qualidade do leite cru refrigerado processado em uma indústria de Minas Gerais. Arquivo Brasileiro de Medicina Veterinária e Zootecnia, 64:471-478.

Paixão MG, Lopes MA, Pinto SM \& Abreu LR (2014) Impacto econômico da implantação das boas práticas agropecuárias relacionadas com a qualidade do leite. Revista Ceres, 66:612-621.

Ribas P, Hartmann W, Monardes HG \& Andrade UVCA (2004) Sólidos Totais do Leite em Amostras de Tanque nos Estados do Paraná, Santa Catarina e São Paulo. Revista Brasileira de Zootecnia, 33:2343-2350.

SEAB - Secretaria de Estado da Agricultura e do Abastecimento (2013) Cultura - Análise da Conjuntura Agropecuária Ano 2012/ 13 - Leite. Available at: <http://www.agricultura.pr.gov.br/arquivos/File/deral/Prognosticos/leite_2012_13.pdf >. Accessed on: January $21^{\text {st }}, 2014$.

Shuster DE, Harmon RJ, Jackson JA \& Hemken EW (1991) Suppression of milk production during endotoxin-induced mastitis. Journal of Dairy Science, 74:3763-3774.

SPSS - Statistical procedures for social sciences (2008) SPSS. Version 17. Chicago, Survey Tips. CD ROM.

Stelwagen K (2011) Mammary Gland, Milk Biosynthesis and Secretion: Lactose. In: Roginski H, Fuquay JW \& Fox PF (Eds.) Encyclopedia of Dairy Sciences. London, Elsevier. p.367-372.

Vieira VF (2010) Características físico-químicas e sensoriais de queijos mussarela elaborados a partir de leites com diferentes contagens de células somáticas. Dissertação de Mestrado. Universidade Estadual do Sudoeste da Bahia, Ilhéus. 71p.

Zoccal R (2008) Cai o número de produtores e sobe a produção de leite em Minas Gerais. Available at: <http://www.cileite.com.br/

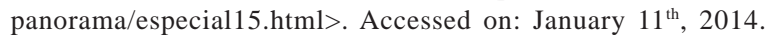

Zoccal R, Alves ER \& Gasques JG (2011) Diagnóstico da pecuária de leite nacional: estudo preliminar: contribuição para o plano pecuário 2012. Available at: <http://www.cnpgl.embrapa.br/nova/ Plano_Pecuario_2012.pdf >. Accessed on: January 19 2014. 